\title{
Sphingolipid accumulation causes mitochondrial dysregulation and cell death
}

\author{
Jeffrey Knupp ${ }^{1}$, Fernando Martinez-Montañés ${ }^{2,4}$, Francoise Van Den Bergh ${ }^{3}$, Stephanie Cottier ${ }^{2}$, Roger Schneiter ${ }^{2}$, Daniel Beard ${ }^{3}$ and \\ Amy Chang ${ }^{*, 1}$
}

Sphingolipids are structural components of cell membranes that have signaling roles to regulate many activities, including mitochondrial function and cell death. Sphingolipid metabolism is integrated with numerous metabolic networks, and dysregulated sphingolipid metabolism is associated with disease. Here, we describe a monogenic yeast model for sphingolipid accumulation. A csg2 $\Delta$ mutant cannot readily metabolize and accumulates the complex sphingolipid inositol phosphorylceramide (IPC). In these cells, aberrant activation of Ras GTPase is IPC-dependent, and accompanied by increased mitochondrial reactive oxygen species (ROS) and reduced mitochondrial mass. Survival or death of $\operatorname{csg} 2 \Delta$ cells depends on nutritional status. Abnormal Ras activation in $\operatorname{csg} 2 \Delta$ cells is associated with impaired Snf1/AMPK protein kinase, a key regulator of energy homeostasis. $\operatorname{csg} 2 \Delta$ cells are rescued from ROS production and death by overexpression of mitochondrial catalase Cta1, abrogation of Ras hyperactivity or genetic activation of Snf1/AMPK. These results suggest that sphingolipid dysregulation compromises metabolic integrity via Ras and Snf1/AMPK pathways.

Cell Death and Differentiation (2017) 24, 2044-2053; doi:10.1038/cdd.2017.128; published online 11 August 2017

Sphingolipids are critical structural molecules in cell membranes, forming membrane microdomains by associating with cholesterol and specific proteins. ${ }^{1}$ Sphingolipid metabolites are also important signaling molecules linked to multiple other metabolic pathways with kinases and phosphatases as regulatory targets. ${ }^{2,3}$ Sphingolipids have roles in numerous cell processes, including regulation of mitochondrial function, cell death and aging. ${ }^{2,4}$ Cellular sphingolipid homeostasis is maintained by control of synthesis, breakdown and interorganellar transport of sphingolipid metabolites. ${ }^{1}$ The importance of sphingolipids is underscored by several lysosomal storage disorders, including Tay Sachs, Gaucher and Nieman-Pick diseases, which are attributable to defective sphingolipid breakdown; similarly, a hereditary sensory neuropathy is caused by accumulation of abnormal sphingolipid metabolites. ${ }^{5}$

Sphingolipids are regulated in response to metabolic need by the TOR signaling network that operates in two multiprotein complexes, TORC1 and TORC2. ${ }^{6}$ TORC1 participates in coordinating cell growth with nutrient availability; cell growth is regulated via numerous effectors, including those promoting protein synthesis, ribosome biogenesis and cell cycle progression. In response to nitrogen deprivation, TORC1 signaling is inhibited and the first step in sphingolipid synthesis is derepressed via phosphorylation of the negative regulators, Orm1 and Orm2. ${ }^{7,8}$ The TORC2 signaling pathway also phosphorylates the Orm proteins to derepress sphingolipid synthesis, and regulates ceramide synthase, which catalyzes a central step in sphingolipid synthesis. ${ }^{9,10}$ Calcium-mediated signaling also participates in regulating sphingolipid homeostasis. The $\mathrm{Ca}^{2+}$-dependent phosphatase calcineurin antagonizes TORC2 activation of ceramide production, ${ }^{10}$ and together with the $\mathrm{Ca}^{2+}$ regulated transcription factor Crz1 represses sphingolipid synthesis by activating ORM2 transcription. ${ }^{11}$ Recent work shows that Snf1/AMPK, a key regulator of energy metabolism, responds to changes in sphingolipid homeostasis. ${ }^{12,13}$ These pathways involved in regulating and responding to sphingolipids are evolutionarily conserved.

In Saccharomyces cerevisiae, the early steps in sphingolipid synthesis are similar to those in mammalian cells and take place in the endoplasmic reticulum (ER). As in mammalian cells, newly synthesized ceramide in yeast is transported from ER to Golgi to form complex sphingolipids. In yeast, a phosphoinositol head group is added to ceramide to form inositol phosphorylceramide (IPC), a complex sphingolipid. Two additional complex sphingolipids, MIPC and M(IP)2C are produced upon IPC mannosylation and attachment of a second phosphoinositol head group, respectively. IPC mannosylation is catalyzed by two enzyme complexes, Csg1/Csg2 and Csg2/Csh1. ${ }^{14}$ In csg2 $\Delta$ cells, IPC builds up and $\mathrm{Ca}^{2+}$ accumulates concomitantly. In csg2 $\Delta$ cells as in mammalian cells accumulating complex sphingolipids, there is also increased production of reactive oxygen species (ROS). ${ }^{15}$

In this report, we show mitochondrial dysfunction and ROS generation are linked to aberrant activation of Ras/ protein kinase A (PKA) signaling in csg2 $\Delta$ cells. The Ras/PKA signaling pathway is involved in regulating cellular response to

\footnotetext{
${ }^{1}$ Department of Molecular Cellular and Developmental Biology, University of Michigan, Ann Arbor, MI, USA; ${ }^{2}$ Department of Biology, University of Fribourg, Fribourg, Switzerland and ${ }^{3}$ Department of Molecular and Integrative Physiology, University of Michigan, Ann Arbor, MI, USA

*Corresponding author: A Chang, Department of Molecular Cellular and Developmental Biology, University of Michigan, 830 North University, Ann Arbor, Ml 48109, USA. Tel: +1 734647 7964; Fax: +1 734647 0884; E-mail: amychang@umich.edu

${ }^{4}$ Current address: Department of Biochemistry and Molecular Biology, University of Southern Denmark, Campusvej 55, 5230 Odense C, Denmark.

Received 09.5.17; revised 19.6.17; accepted 04.7.17; Edited by L Scorrano; published online 11.8.17
} 
the major nutrient sources, carbon and nitrogen. ${ }^{16}$ Normally, when cells are challenged by nitrogen deprivation or loss of even a single essential amino acid, increased electron transport chain (ETC) activity is required even in cells growing in plentiful glucose when they engage predominantly in fermentative instead of respiratory metabolism. In csg2 cells, aberrantly activated Ras inhibits downstream signaling by Snf1/AMPK kinase, preventing the ETC from responding appropriately to nutritional status; the catastrophic result is massive ROS generation and rapid cell death. $\operatorname{csg} 2 \Delta$ cells are rescued from ROS and death by overexpression of mitochondrial catalase to detoxify ROS, abrogation of Ras or genetic activation of Snf1/AMPK activity. Our results show that sphingolipid dysregulation interferes with mitochondrial regulation.

\section{Results}

Death of csg2 $\Delta$ cells upon nitrogen deprivation is associated with ROS production. Perturbed sphingolipid synthesis in csg2 $\Delta$ cells is associated with constitutively increased production of ROS, as revealed by bright dihydroethidium (DHE) staining throughout the cell (Figure 1a). When these cells are challenged by deprivation of a nitrogen source or a single essential amino acid, cell numbers producing ROS are greatly increased. DHE fluorescence in wild-type cells growing in synthetic complete (SC) medium with glucose is faintly cytoplasmic, indicating no ROS generation; however, upon nitrogen deprivation, a slight increase in fluorescent mitochondrial puncta is apparent (Figure 1a). ROS accumulation in $\operatorname{csg} 2 \Delta$ cells is associated with cell death, as measured by colony-forming assay, with $\sim 10 \%$ viability after $4 \mathrm{~h}$ of nitrogen deprivation (Figure $1 \mathrm{~b}$ ); absolute colony numbers are in Supplementary Table 1. Propidium iodide staining confirms death of csg2 $\Delta$ cells (Supplementary Figure 1A). Few annexin V-FITC staining cells were observed during a time course of nitrogen deprivation (Supplementary Figure 1B), suggesting death is non-apoptotic. Our results are consistent with a previous report that $(\operatorname{csg} 1 \Delta \operatorname{csh} 1 \Delta)$ cells lacking enzymatic activity to mannosylate IPC die upon nitrogen deprivation. ${ }^{17}$ Consistent with accumulating ROS, csg2 $\Delta$ cells have increased sensitivity to oxidative stress (Supplementary Figure 1C). As loss of Csg2 causes a block in a late step in the sphingolipid synthesis pathway (diagrammed in Figure 1c), a genetic approach was taken to determine whether cell death is associated with accumulation of upstream sphingolipid precursors (quantitated by mass spectrometry in Figure $2 b$ below) or loss of downstream complex sphingolipids. A kei1-1 csg2s double mutant was constructed to prevent IPC accumulation by a temperature-sensitive block in IPC synthase activity (Figure $1 \mathrm{c}$ and Sato et al. ${ }^{18}$ ); these cells are largely resistant to death upon nitrogen deprivation (Figure 1b). By contrast, ipt1 $1 \Delta \operatorname{csg} 2 \Delta$ cells, with a block in the production of the final and most abundant complex sphingolipid $\mathrm{M}(\mathrm{IP})_{2} \mathrm{C}$ are not rescued from nitrogen deprivation-induced death. Moreover, a single ipt1 $\Delta$ mutant resists cell death under these conditions (Figure 1b). These results suggest that death of $\operatorname{csg} 2 \Delta$ cells is accounted for by IPC accumulation rather than loss of downstream complex sphingolipids.

As the mitochondrial ETC is a major source of ROS, loss of mitochondrial DNA was induced to generate $\operatorname{csg} 2 \Delta$ cells lacking a functional ETC. In $\operatorname{csg} 2 \Delta$ rhoO cells, nitrogen deprivation-induced death is suppressed (Figure 1d), and both constitutive and nitrogen deprivation-induced ROS production are suppressed (Figure 2a). Similarly, addition of the protonophore carbonyl cyanide $m$-chlorophenylhydrazone (CCCP) to csg2 $\Delta$ cells suppresses death (Figure 1d), likely by abolishing ROS generation. ${ }^{19}$ Both ROS and death in $\operatorname{csg} 2 \Delta$ cells are abrogated by overexpression of mitochondrial catalase, encoded by CTA1, which detoxifies hydrogen peroxide generated from superoxide ${ }^{20}$ (Figures 1d and 2a). These results support the hypothesis that ETC-generated ROS promotes cell death.

ROS production in csg2 $\Delta$ cells is abrogated by removing glucose. Rescue from death in csg2 $\mathrm{choO}$ cells suggests that accumulated IPC may contribute to ROS generation by mitochondria. Lipid mass spectrometry shows that IPC is increased in csg2 2 cells; in isolated mitochondria, IPC level/mitochondrial protein is similar in wild-type and $\operatorname{csg} 2 \Delta$ cells (Figure $2 b$ ). Mitochondria in csg2 $\Delta$ cells were examined by tetramethylrhodamine (TMRM) staining, which is sequestered by active mitochondria according to the membrane potential. ${ }^{21}$ Control experiments show that TMRM fluorescence reflects mitochondrial membrane potential (MMP) as it is decreased by ETC inhibitors antimycin and rotenone, and the protonophore CCCP, and increased by the ATP synthase inhibitor triethyltin (TET) (Supplementary Figure 2A). TMRM fluorescence is reduced in $\operatorname{csg} 2 \Delta$ cells, indicating diminished relative MMP (Figure $2 c$ ). Additional images of TMRM fluorescence in $\operatorname{csg} 2 \Delta$ cells are shown in Supplementary Figure 2B. The membrane potential reflects ETC activity; when wild-type cells growing exponentially in nitrogen-replete medium with $2 \%$ glucose are shifted to nitrogen-free medium for $1 \mathrm{~h}$, the relative MMP is greatly increased (Figure 2c and Supplementary Figure 2C). In agreement, nitrogen deprivation has been reported to increase respiratory metabolism in fermenting yeast and also human cells. ${ }^{22,23}$ By contrast with wild-type cells, constitutively lower MMP in $\operatorname{csg} 2 \Delta$ cells fails to increase to a significant extent after 1-h nitrogen deprivation (Supplementary Figure $2 \mathrm{C}$ ). Loss of viability in csg2 $\Delta$ cells correlates with inability to increase MMP. Notably, during nitrogen deprivation, removing glucose rescues viability in $\operatorname{csg} 2 \Delta$ cells, and growth in a nonfermentable carbon source such as glycerol also prevents death by nitrogen deprivation (Figure 2d). Altogether, these data suggest that susceptibility to death is glucose dependent, and associated with loss of MMP response to nitrogen deprivation.

$\mathrm{O}_{2}$ consumption reflects ETC activity. During exponential growth in plentiful glucose and nitrogen, respiration in wildtype cells is repressed in favor of fermentation, even in air; this is called the Crabtree effect. ${ }^{16}$ Under these conditions, the ETC maintains low activity as revealed by a MMP (Figure 2c). To examine mitochondrial regulation further, cellular $\mathrm{O}_{2}$ consumption was measured. Figure 3a shows $\mathrm{O}_{2}$ 

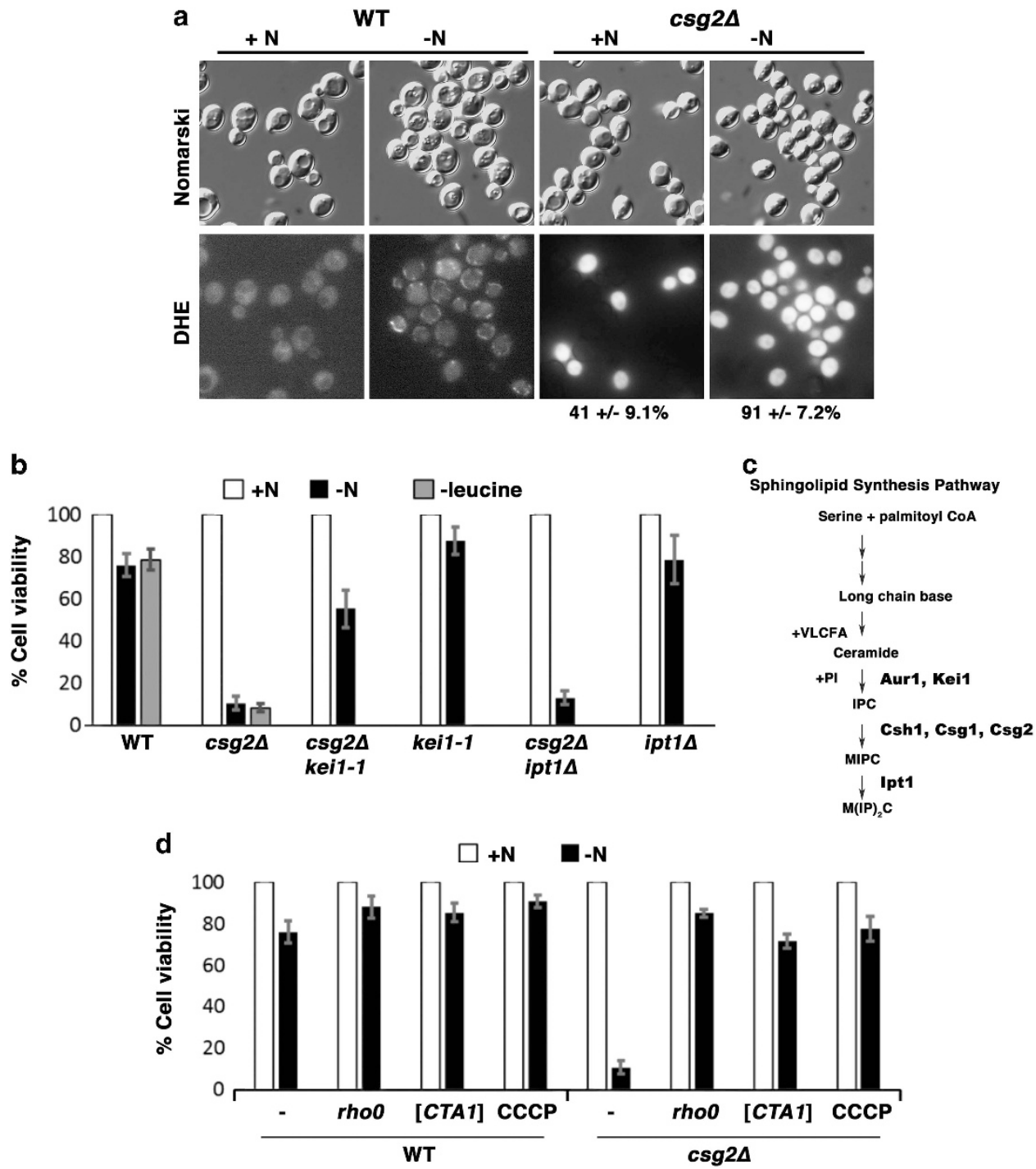

Figure 1 Increased ROS production during nitrogen deprivation leads to rapid cell death of $\operatorname{csg} 2 \Delta$ cells. (a) ROS accumulate constitutively in $\operatorname{csg} 2 \Delta \operatorname{cells}$. WT and $\operatorname{csg} 2 \Delta$ cells exponentially growing in SC medium or shifted to nitrogen-depleted medium for $1 \mathrm{~h}$ were stained with DHE. Fluorescence images from cells \pm nitrogen deprivation were imaged for the same exposure time and adjusted using identical Photoshop settings. Images of $\operatorname{csg} 2 \Delta$ cells were adjusted to a lesser intensity than that of wild type because DHE fluorescence is much brighter in $\operatorname{csg} 2 \Delta$ cells. (b) Nitrogen deprivation induces rapid cell death in $\operatorname{csg} 2 \Delta$ cells. Cells exponentially growing in SC medium were washed with water, and shifted to SC without leucine or nitrogen deprivation medium for $4 \mathrm{~h}(-\mathrm{N})$. Cell viability was assayed by colony-forming assay, expressed as a percentage of cells plated without nitrogen deprivation $(+\mathrm{N})$. Absolute colony numbers for cell viability assays are in Supplementary Table 1. kei1-1 csg2 $\Delta$ cells were assayed at $30^{\circ} \mathrm{C}$, the semi-permissive temperature. ${ }^{18}$ Mean values from $n \geq 3$ with error bars indicating S.E.M. (c) Simplified diagram of sphingolipid synthesis pathway including major intermediates, and relevant proteins catalyzing specific steps. (d) As in (b). Expression of Cta1 catalase activity was induced by washing cells with water and incubating in methionine-free SC-uracil medium for $3 \mathrm{~h}$ before nitrogen deprivation. Mitochondrial catalase activity was increased $>30 \times$ after induction of the MET17 promoter by comparison with that in cells without the pMETCTA1 construct

flux in wild-type cells exponentially growing in ample glucose. Addition of TET, an ATP synthase inhibitor, completely blocks $\mathrm{O}_{2}$ flux, indicating that $\mathrm{O}_{2}$ consumption entirely reflects coupled respiration. CCCP addition restores $\mathrm{O}_{2}$ consumption, confirming available reducing equivalents for the ETC. By comparison with wild-type cells, $\mathrm{O}_{2}$ flux in $\operatorname{csg} 2 \Delta$ cells is diminished (Figure $3 a$ ). In wild-type cells, nitrogen deprivation induces a slight but significant increase in $\mathrm{O}_{2}$ consumption, suggesting an acute increase of mitochondrial ETC activity (Figure 3b). However, no increase in $\mathrm{O}_{2}$ consumption by $\operatorname{csg} 2 \Delta$ cells was observed after $1 \mathrm{~h}$ of nitrogen deprivation.
When respiration is completely derepressed during growth on glycerol, wild-type as well as csg2 $\Delta$ cells have much higher $\mathrm{O}_{2}$ consumption (note scale of axis in Figure $3 \mathrm{~b}$, right); remarkably, under respiratory conditions, $\mathrm{O}_{2}$ consumption of $\operatorname{csg} 2 \Delta$ cells is not impaired, and respiration is further increased upon nitrogen deprivation in wild-type as well as csg2 $\Delta$ cells (Figure $3 \mathrm{~b}$, right panel). In cells growing in glycerol, respiration in isolated mitochondria is identical in wild-type and $\operatorname{csg} 2 \Delta$ cells (Supplementary Figure 3 ). Thus, mitochondrial defects in $\operatorname{csg} 2 \Delta$ cells are linked to repression of respiration by glucose. 
a

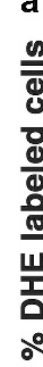

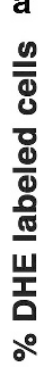

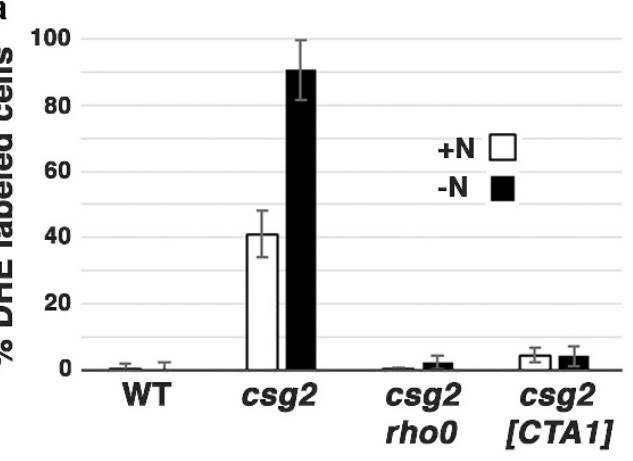

b

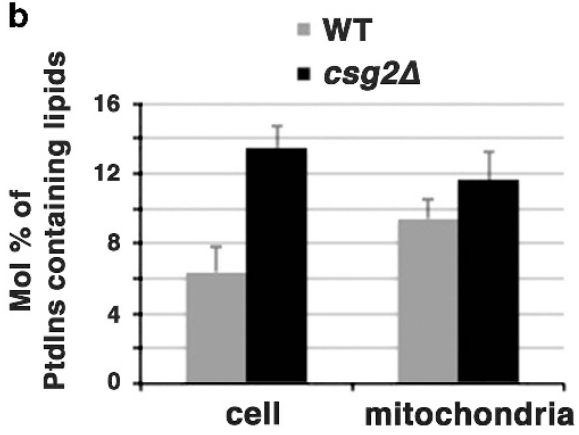

c $\operatorname{csg} 2 \Delta$

$\mathbf{W T}+\mathbf{N}$

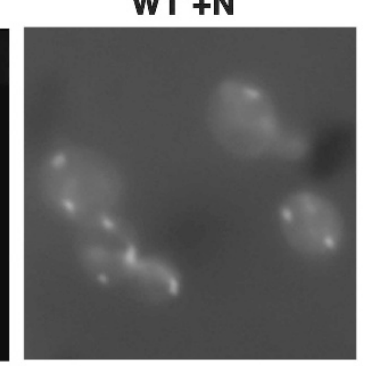

WT -N
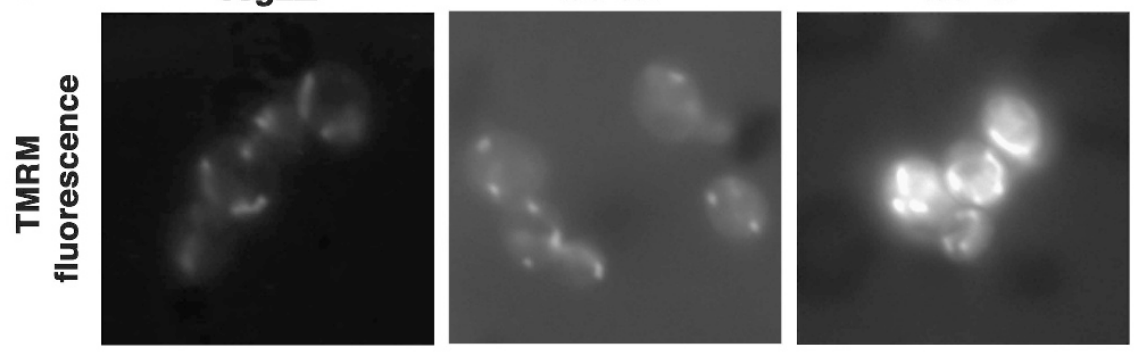

- SC (+glucose)

d $\square-\mathrm{N}$

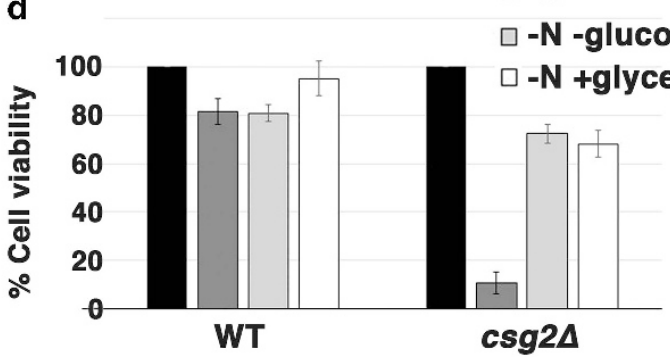

$\square-\mathbf{N}$-glucose

$\square-\mathrm{N}+\mathrm{glycerol}$

Figure 2 ROS accumulation and mitochondrial impairment is dependent on nutritional status in $\operatorname{csg} 2 \Delta$ cells. (a) ROS accumulation induced by nitrogen deprivation is suppressed in csg2 2 rho0 cells as well as CTA1 overexpression (as described in Figure 1d). DHE-stained cells were quantitated as a percentage of total cell population. Mean values \pm S.E.M. are indicated; 50 cells quantitated per experiment; $n=3$. (b) IPC levels in WT and $\operatorname{csg} 2 \Delta$ cell lysate $(P \leq 0.005)$ and isolated mitochondria $(P=0.12)$, as measured by mass spectrometry. (c) TMRM fluorescence reflects MMP. Relative MMP in wild-type cells is increased by nitrogen deprivation; MMP in csg2 $\triangle$ cells is reduced by comparison with that in WT. Images were taken at identical exposure times and brightness and contrast were adjusted using identical Photoshop settings. (d) Death of csg2 $\Delta$ cells during nitrogen deprivation is mediated by glucose. Cells remain viable during nitrogen deprivation in the absence of glucose or in the presence of the nonfermentable carbon source, glycerol. Viability assay as described, and mean values \pm S.E.M. for WT and $\operatorname{csg} 2 \Delta$ cells replotted from Figure $1 \mathrm{~b}$

Mitochondrial mass is reduced in csg2 $\Delta$ cells. To account for reduced $\mathrm{O}_{2}$ consumption in csg2 $\Delta$ cells exponentially growing in glucose, western blot was used to survey mitochondrial protein levels. Figure $3 c$ shows the level of the ETC component, Cox $2 p$, subunit II of cytochrome c oxidase (COX; ETC complex IV) is significantly reduced in $\operatorname{csg} 2 \Delta$ cells (to $\sim 30 \%$ of wild-type) when growing in glucose but not in glycerol or during the post-diauxic shift (PDS). The level of mitochondrial outer membrane porin, Por1/VDAC, is similarly diminished selectively during growth in glucose (Figure 3c).

Cox2 is a COX catalytic core component encoded by a mitochondrial gene,${ }^{24}$ whereas Por1 is encoded by a nuclear gene. To understand reduced Cox2 levels in csg2 $\Delta$ cells, mitochondrial copy number of the COX2 gene was estimated by PCR, and normalized to nuclear ACT1 DNA. Mitochondrial mass in csg2 $\Delta$ cells is $\sim 0.2-0.4$ that in wild-type cells (Figure $3 d$ ), accounting for decreased levels of Cox2 protein and decreased $\mathrm{O}_{2}$ consumption. By contrast, nuclear POR1 DNA, normalized to nuclear ACT1 DNA, in $\operatorname{csg} 2 \Delta$ cells is similar to that in wild-type, suggesting the possibility that decreased Por1 protein in csg2 $2 \Delta$ cells is a post-translational effect, caused by decreased mitochondrial import or stability.

Activation of Ras signaling in csg2 $\Delta$ cells. As the signaling GTPase, Ras, is a key regulator of cellular response to glucose and responds to mitochondrial dysfunction, ${ }^{25}$ Ras signaling was examined in $\operatorname{csg} 2 \Delta$ cells by visualizing localization of an RBD-GFP construct, comprised of a RasGTP binding domain fused to GFP. ${ }^{26}$ As reported previously, RBD-GFP is predominantly localized intracellularly in exponentially growing wild-type cells, visualized as cytosolic and 

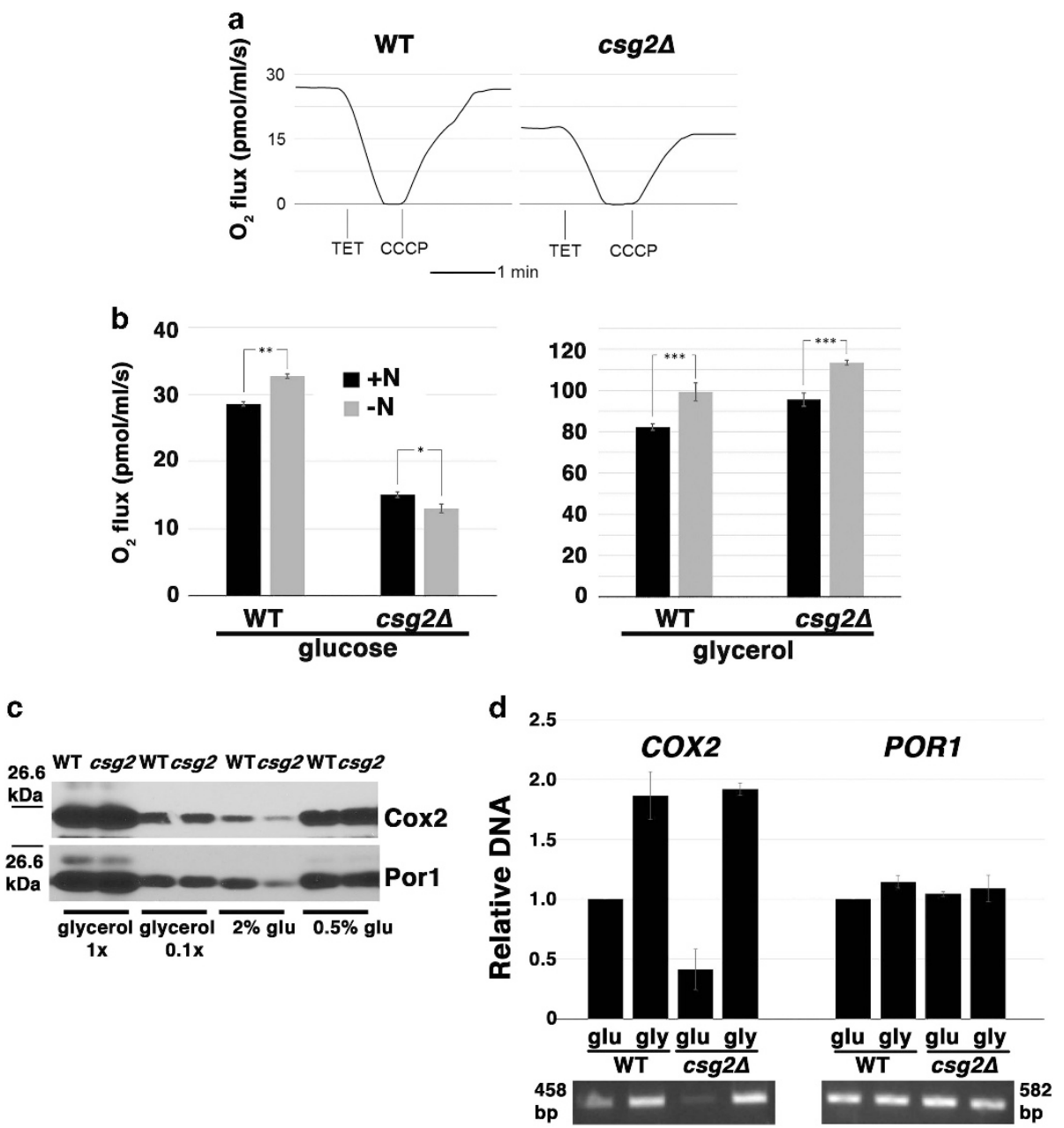

Figure 3 Reduced $\mathrm{O}_{2}$ consumption and mitochondrial mass in csg2 $\Delta$ cells during growth in glucose. (a) Cellular $\mathrm{O}_{2}$ consumption in wild-type and csg2 $\Delta$ cells exponentially growing in SC ( $2 \%$ glucose). Representative cellular $\mathrm{O}_{2}$ consumption in SC ( $2 \%$ glucose) was measured in an oxygraph, normalized to $\mathrm{OD}_{600} / \mathrm{ml} ; \mathrm{TET}^{2}$ and CCCP were added as indicated. (b) Mean cellular $\mathrm{O}_{2}$ consumption (as described in a) for $n=3$ independent experiments \pm S.E.M. In SC glucose, $\mathrm{O}_{2}$ consumption is increased by nitrogen deprivation $(1 \mathrm{~h})$ in WT, but not $\operatorname{csg} 2 \Delta$ cells. ${ }^{* *} P \leq 0.025,{ }^{*} P \leq 0.05$. In SC glycerol, $\mathrm{O}_{2}$ consumption is increased by nitrogen deprivation in both WTand csg2 $\Delta$ cells. ${ }^{* * \star} P \leq 0.01$. (c) Western blot of mitochondrial proteins in WTand csg2 $\Delta$ cells growing in SC medium with $3 \%$ glycerol, $2 \%$ glucose or $0.5 \%$ glucose. In glucose, Cox2 and Por1 protein levels are reduced in csg2 $\triangle$ cells. (d) Mitochondrial DNA is reduced in csg2 $\triangle$ cells, reflecting decreased mitochondrial mass. Mitochondrial COX2 DNA and nuclear POR1 DNA isolated from wildtype and $\operatorname{csg} 2 \Delta$ cells growing in glucose and glycerol was determined by PCR, quantitated by Image $J$, and normalized to ACT1 DNA. $n=3$ experiments

nuclear fluorescence (Figure 4a, left panel and Belloti et $\left.a l^{27}\right)$. By contrast, RBD-GFP localization at the plasma membrane is increased in cells expressing constitutively active Ras2 ${ }^{\text {Val19 }}$ (Figure $4 a$, left panel). Similarly, RBD-GFP fluorescence and plasma membrane localization in $\operatorname{csg} 2 \Delta$ cells suggest accumulated activated Ras (Figure 4a, left panel). Importantly, IPC accumulation induces Ras activation as RBD-GFP localization to the plasma membrane is diminished in kei1-1 csg2 $\Delta$ as in wild-type cells (Figure $4 a$, left panel).

Cytoplasmic catalase (encoded by CTT1) is negatively controlled by Ras-mediated signaling. ${ }^{28}$ As another indicator of Ras activity, cytoplasmic catalase activity was assayed in cell lysate after ETC perturbation with low doses of antimycin (inhibitor of complex III), azide (inhibitor of COX) or CCCP in exponentially growing cells. Cytoplasmic catalase activity is decreased in response to impaired ETC function although cell viability is not affected (Figure 4b). These results support activation of Ras by mitochondrial dysfunction. In $\operatorname{csg} 2 \Delta$ cells, cytoplasmic catalase activity is significantly reduced, similar to that in cells expressing constitutively active RAS2 $2^{\text {Val19 }}$ (Figure 4a, right panel). Mitochondrial catalase was assayed in isolated mitochondria, and this activity is also decreased in cells expressing Ras2 ${ }^{\mathrm{Val19}}$ as well as in $\operatorname{csg} 2 \Delta$ cells (Supplementary Figure $4 \mathrm{~A}$ ). Hyperactive Ras2 $2^{\text {Val19 }}$ also increases heat shock sensitivity, ${ }^{29}$ and $\operatorname{csg} 2 \Delta$ cells have diminished viability after heat stress (Supplementary Figure 4B). Taken together, three independent assays show that Ras is constitutively activated in $\operatorname{csg} 2 \Delta$ cells.

Ras activation is dependent on ample glucose; upon glucose depletion during PDS or growth in glycerol, increased cytoplasmic catalase activity reflects Ras inactivation (Figure 4c). So during nitrogen deprivation (in the presence of glucose) in wild-type cells, cytoplasmic catalase activity is increased, indicating Ras inactivation (Figure 4c). Conversely, hyperactive Ras2 $2^{\text {Val19 }}$ prevents increased MMP during 

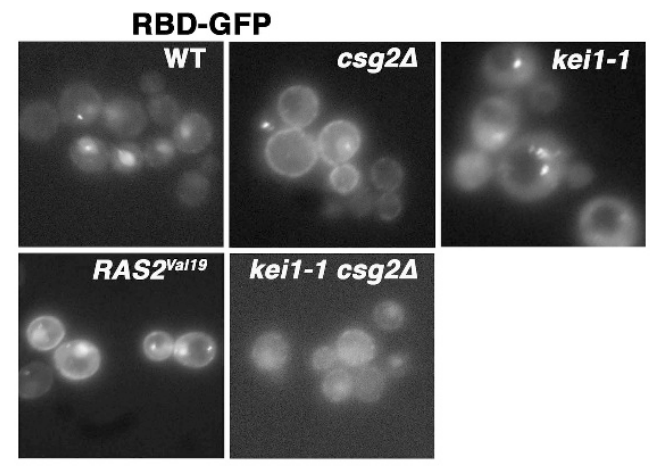

b
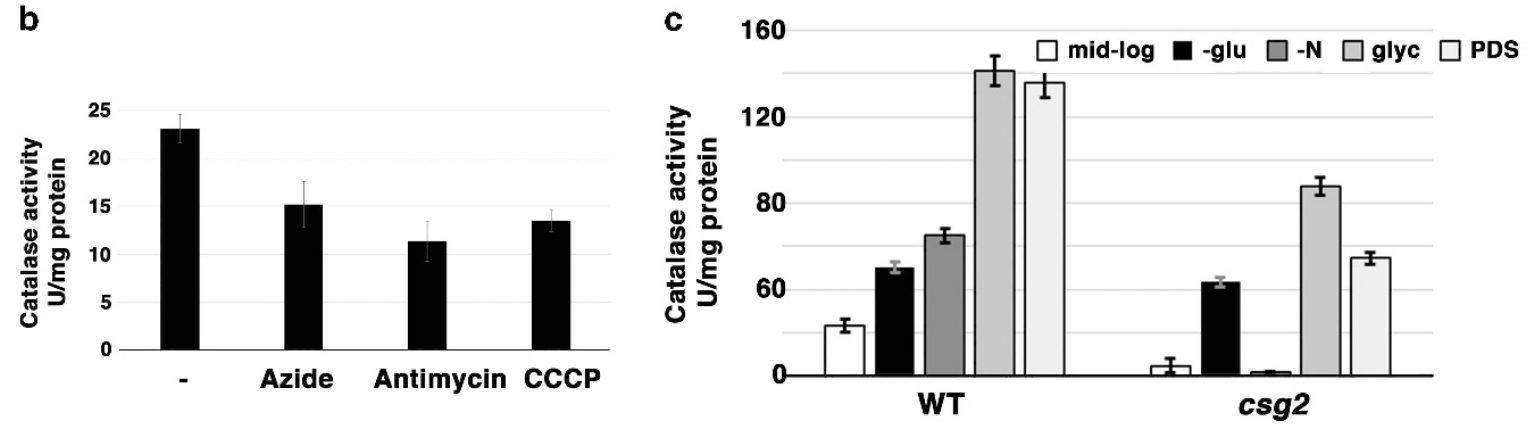

d
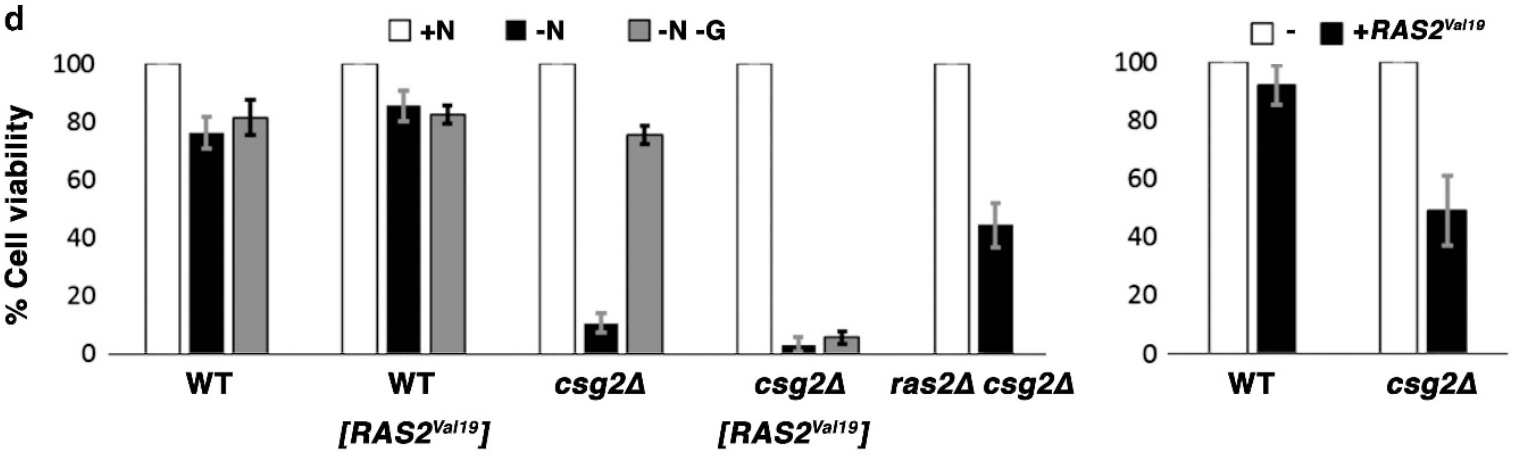

e
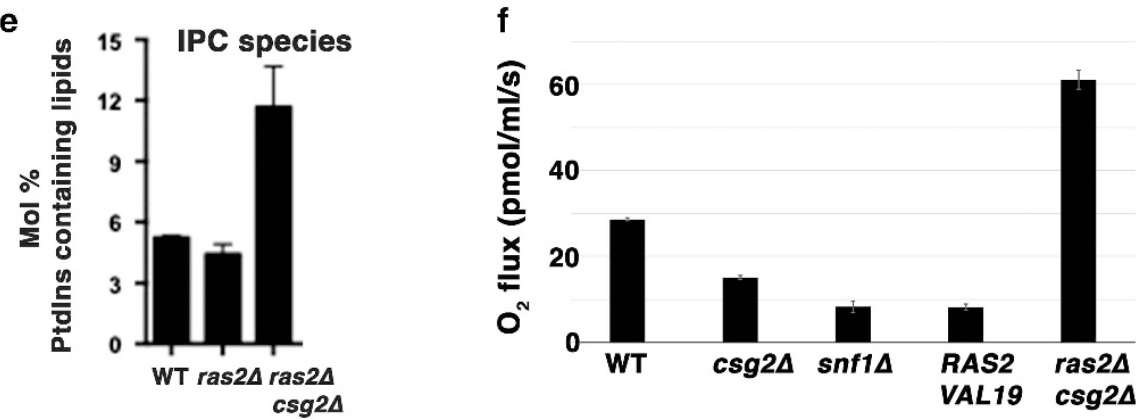

Figure 4 Ras2 signaling is dysregulated by sphingolipid accumulation in csg2 $\Delta$ cells. (a) Ras is activated in csg2 $\Delta$ cells as assayed by RBD-GFP localization (left panel). Cells exponentially growing at $30^{\circ} \mathrm{C}$ were visualized by fluorescence microscopy. Right panel, cytoplasmic catalase activity $(n=3)$. Expression of Ras2 ${ }^{\text {Vallig }}$ was induced by washing cells with water and incubating in methionine-free SC-uracil medium for $1 \mathrm{~h}$. (b) ETC inhibition activates Ras. Antimycin A (100 $\mu \mathrm{M})$, azide (10 $\mu \mathrm{M})$ and CCCP (10 $\mu \mathrm{M})$ were added to cells exponentially growing in SC for $2 \mathrm{~h}$. Catalase activity was measured in cell lysates as described in Materials and methods section, and expressed as U/mg protein; $n=3$ experiments \pm S.E.M. (c) Ras activity in mid-log cells shifted from SC $2 \%$ glucose to SC minus glucose or nitrogen deprivation medium for $1 \mathrm{~h}$. Cytoplasmic catalase activity was also measured in cells during PDS, and growing in SC $3 \%$ glycerol; $n=3 \pm$ S.E.M. (d) Effect of hyperactive Ras2 ${ }^{\text {Val19 }}$ on cell viability, as assayed in Figure 1b. Cells were shifted to methionine-free medium for $3 \mathrm{~h}$ to induce Ras2 ${ }^{\text {Val19 }}$ expression. Left panel, cells were incubated in nitrogen deprivation medium with or without glucose for $1 \mathrm{~h}$. Right panel, after induction of Ras2 ${ }^{\text {val19 }}$ for $3 \mathrm{~h}$, cells were incubated in SC medium for $1 \mathrm{~h}$ and plated for colony formation to assess viability. (e) IPC is accumulated in ras $2 \Delta \operatorname{csg} 2 \Delta$ cells by comparison with WT cells, as measured by lipid mass spectrometry. (f) $\mathrm{O}_{2}$ consumption in ras $2 \Delta \operatorname{csg} 2 \Delta$ cells exceeds that in WT cells. Left panel, $\mathrm{O}_{2}$ consumption is depressed in cells expressing RAS2 ${ }^{\text {Val19 }}$ for $3 \mathrm{~h}$. Right panel, western blot showing Cox2 protein level is increased (derepressed) in ras2 $\Delta$ csg2 $\Delta$ cells exponentially growing in SC medium with $2 \%$ glucose. PGK is shown as the loading control 
nitrogen deprivation (Supplementary Figure 4C). In csg2 $\Delta$ cells during PDS or growth in glycerol, cytoplasmic catalase activity is increased to a lesser extent than in wild-type cells (perhaps because Ras is initially in a more activated state). During nitrogen deprivation in $\operatorname{csg} 2 \Delta$ cells, cytoplasmic catalase activity fails to increase, indicating that aberrantly activated Ras cannot respond normally to the nutritional cue (Figure 4c).

Simply removing glucose can rescue csg2 $\Delta$ cells from death during nitrogen deprivation (Figures $2 d$ and $4 d$, left panel), but hyperactive Ras $2^{\text {Val19 }}$ bypasses this effect (Figure 4d, left panel). Even without nitrogen deprivation, expression of Ras2 $2^{\text {Val19 }}$ for $3 \mathrm{~h}$ in $\operatorname{csg} 2 \Delta$ cells increases ROS generation (data not shown) with death ensuing (Figure 4d, right panel). These results show that aberrant Ras activation leads to death in $\operatorname{csg} 2 \Delta$ cells. Consistent with a detrimental effect of activated Ras, nitrogen deprivation-induced death is abrogated in ras $2 \Delta \operatorname{csg} 2 \Delta$ double mutant cells (Figure $4 d$, left panel). Suppression in ras $2 \Delta \operatorname{csg} 2 \Delta$ cells is not associated with a reversal in IPC accumulation (Figure 4e). Along with rescued viability, $\mathrm{O}_{2}$ consumption in ras $2 \Delta \operatorname{csg} 2 \Delta$ cells is $\sim$ twice that seen in wild-type cells exponentially growing in $2 \%$ glucose (Figure 4f, left panel). Conversely, respiration is repressed in wild-type cells expressing constitutively activated

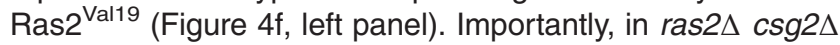
cells, regulatory events are restored in order to derepress respiration and prevent ROS accumulation during nitrogen deprivation. Along with derepressed respiration, Cox2 protein level in ras $2 \Delta \operatorname{csg} 2 \Delta$ cells is significantly higher (Figure 4f, right panel).

Dysregulation of the Snf1/AMPK pathway. Repression of mitochondrial function by glucose is regulated by Snf1 kinase, the founding member of the AMP-activated protein kinase family that modulates energy homeostasis. ${ }^{16,30}$ In plentiful glucose, Snf1 is negatively regulated by Glc7 protein phosphatase and the Snf1-binding adaptor Reg1; Snf1 becomes constitutively activated in reg1s cells ${ }^{31}$ (diagrammed in Figure 5a). Figure 5a shows that even in the presence of glucose, reg1 $1 \Delta$ cells are derepressed for expression of $A D H 2$, a downstream reporter of Snf1 activity. $^{32}$ If death of $\operatorname{csg} 2 \Delta$ cells is a consequence of aberrant signaling downstream of Ras, loss of Reg1 is predicted to correct the defect. Indeed, upon nitrogen deprivation, reg1s csg2 $\Delta$ double mutants are rescued from ROS accumulation (Supplementary Figure 5A) and death (Figure $5 b$ ). Mitochondrial biogenesis is derepressed in reg1 $1 \Delta \operatorname{csg} 2 \Delta$ cells growing in glucose, as revealed by substantial increases in mitochondrial proteins (Figure $5 c$ ). Providing further support for requisite Snf1 activation during nitrogen deprivation, $\operatorname{csg} 2 \Delta$ cells are rescued from death by a constitutively active Snf1-G53R ${ }^{33}$ (Figure $5 b$ ). A model depicting suppression of Snf1 activity by aberrant Ras activation in csg2 $\Delta$ cells is shown in Figure $5 \mathrm{~d}$. If nitrogen deprivation requires $\mathrm{Snf1}$ activation, snf1 $\Delta$ cells should not survive. As predicted, snf1 $\Delta$ cells die with ROS accumulation upon nitrogen deprivation (Figure $5 \mathrm{~b}$, Supplementary Figure 5B). Moreover, $\mathrm{O}_{2}$ consumption is constitutively decreased in snf1 $\Delta$ cells (Figure 4f), consistent with a Snf1 requirement for mitochondrial biogenesis. ${ }^{30}$

\section{Discussion}

A major finding in this article is that accumulation of the complex sphingolipid IPC in $\operatorname{csg} 2 \Delta$ cells causes nutrientdependent mitochondrial dysfunction and ROS generation (Figures 1 and 2). Aberrant Ras activation is a consequence of IPC accumulation in csg2 $\Delta$ cells as it is prevented in kei1 $\operatorname{csg} 2 \Delta$ double mutant cells (Figure $4 \mathrm{a}$ ). Ras signaling has previously been shown to have a necessary role in response to impaired or reduced mitochondrial function. ${ }^{25}$ Indeed, when the ETC is acutely impaired by inhibitors, Ras signaling is activated (Figure 4b). In addition, when COX assembly is impaired in the absence of Cox $4,{ }^{34}$ there is a slight increase in activated Ras, reflected by decreased cytoplasmic catalase activity and heat shock sensitivity (Figure 4a, Supplementary Figure 4B). Thus, mitochondrial impairment in csg2 $\Delta$ cells may contribute to Ras activation. At present, however, we cannot rule out the possibility that lipid-anchored Ras is activated in $\operatorname{csg} 2 \Delta$ cells by being inappropriately recruited to sphingolipid-enriched membranes.

In csg2 $\Delta$ cells, Ras hyperactivation and mitochondrial dysfunction are linked. It is possible that Ras hyperactivation reduces mitochondrial mass in $\operatorname{csg} 2 \Delta$ cells to $\sim 0.3$ that of wild-type cells, as reflected by decreased levels of mitochondrial DNA and proteins (Figure 3). Ras and its major effector, the PKA signaling pathway, serve as key regulators of mitochondrial function in response to nutritional status. ${ }^{16}$ In glucose, hyperactive Ras ${ }^{\text {Val19 }}$ reduces $\mathrm{O}_{2}$ consumption in wild-type cells (Figure $4 \mathrm{f}$ and $\mathrm{Kim}$ et al. $^{35}$ ), and in $\operatorname{csg} 2 \Delta$ cells, $\mathrm{O}_{2}$ consumption is also reduced. Most importantly, aberrantly active Ras abrogates response to nitrogen deprivation in csg2 $\Delta$ cells (Figure 3b, Supplementary Figure 2C); we propose this acute respiratory response is a protective mechanism in fermenting yeast as well as humans. ${ }^{22,23}$ Increased ETC activity and $\mathrm{O}_{2}$ consumption during stress, including nitrogen deprivation, has been suggested to restrict ROS production by increased efficiency of electron transfer. ${ }^{19,36}$ ROS production in $\operatorname{csg} 2 \Delta$ cells is increased during nitrogen deprivation because the cells are unable to make a metabolic shift to increase respiration, and prevent electron leakage from the respiratory chain to limit ROS production. Nitrogen deprivation signals may also act as a metabolic checkpoint to suppress ATP-consuming activities needed for cell growth and proliferation. ${ }^{37}$ Increased ETC activity (eliciting a dramatic increase in MMP but relatively small increase in $\mathrm{O}_{2}$ consumption) in response to nitrogen deprivation may act as a signaling mechanism to restrict cell growth and proliferation.

During cellular response to nitrogen deprivation, Ras is inhibited in wild-type cells, as reflected by increased cytoplasmic catalase activity; by contrast, in csg2 $\Delta$ cells, Ras is persistently activated (Figure 4c), leading to increased ROS production and death. Death in $\operatorname{csg} 2 \Delta$ cells requires a functional ETC generating ROS (Figures 1d and 2a). Death in $\operatorname{csg} 2 \Delta$ cells is induced by glucose during nitrogen deprivation (Figure $2 \mathrm{~d}$ ) because Ras activation requires glucose. ${ }^{16}$ Paradoxically, during respiratory growth in glycerol, $\operatorname{csg} 2 \Delta$ cells are rescued from death during nitrogen deprivation (Figure 2d), implying that Ras can become inactivated in the absence of glucose in these cells but not in its presence. 

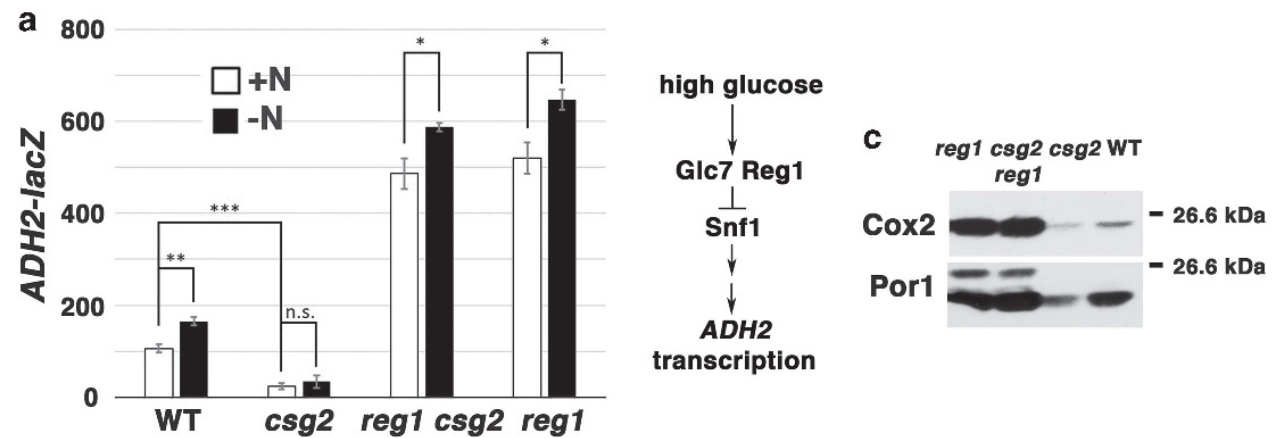

transcription

b

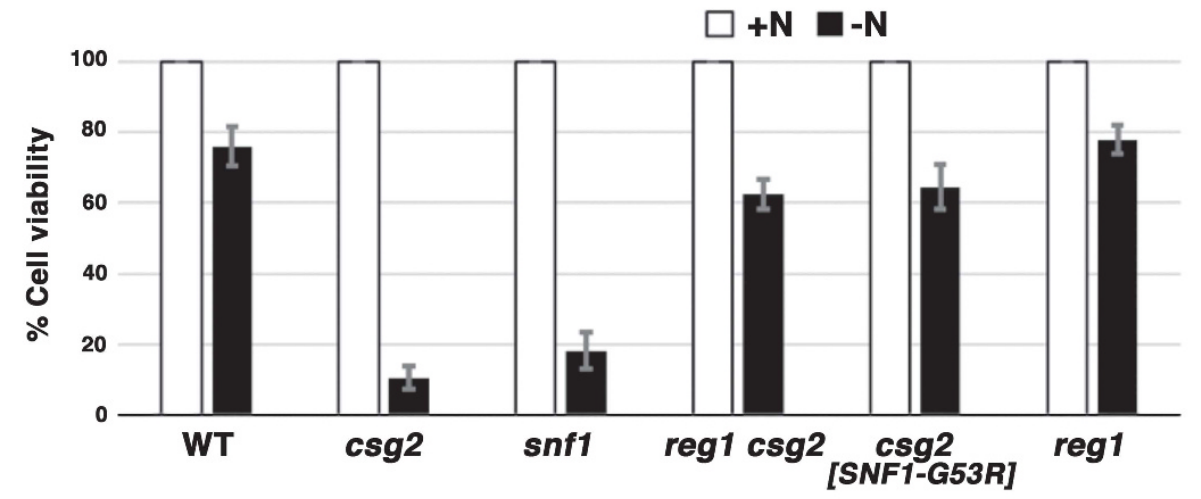

d

+ glucose
+ nitrogen

+ glucose
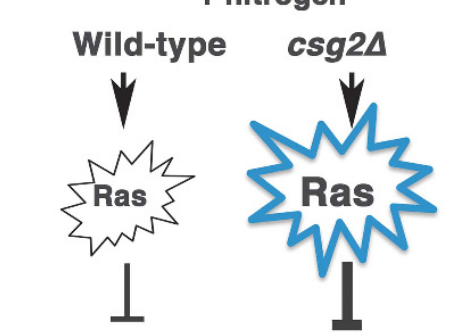

Snf1/AMPK

Snf1/AMPK

Y

mitochondrial

ROS

biogenesis

mitochondrial

biogenesis

- nitrogen
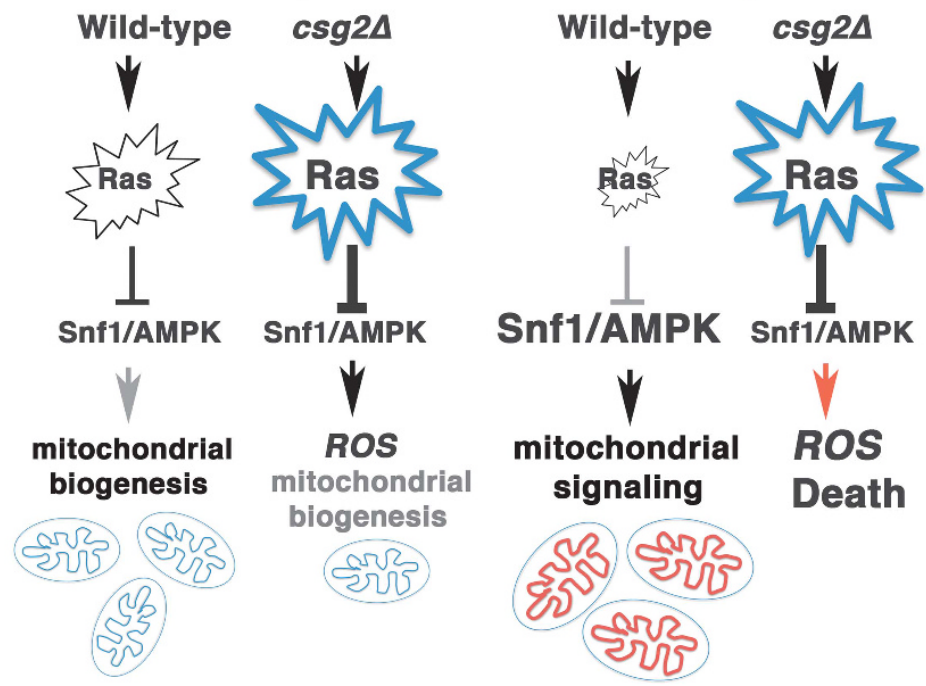

Figure 5 Snf1 activity in csg2 $\Delta$ cells is repressed. (a) Left panel, downstream Snf1 activity is depressed by reg1 $\Delta$, as measured by $A D H 2$-lacZ activity (expressed as $\mu$ mol/ $\mathrm{min} / \mathrm{mg}$ protein). Shown are mean \pm S.E.M.; ${ }^{*} P \leq 0.025,{ }^{*} P \leq 0.05$. Right panel, diagram depicting Snf1/AMPK kinase negatively regulated by Reg1-Glc7 complex. (b) Cell viability is rescued by activated Snf1. reg1 $\Delta \operatorname{csg} 2 \Delta$ cells and $\operatorname{csg} 2 \Delta$ [SNF1-G53R] are rescued from death by nitrogen deprivation. Viability assay as described in Figure 1 b. (c) Western blot showing mitochondrial proteins are upregulated in reg1 $\Delta$ cells. (d) Schematic diagram showing Ras/PKA signaling upstream of Snf1 activity. Snf1 is a key regulator of mitochondrial activity and biogenesis. In wild-type cells, Snf1 activation is required to increase MMP during nitrogen deprivation. In $\operatorname{csg} 2 \Delta$ cells, aberrantly activated Ras represses Snf1 activity leading to ROS production and death during nitrogen deprivation

During nitrogen deprivation, mitochondrial ROS production is increased in csg2 $\Delta$ cells whereas defense against ROS is weakened, as mitochondrial and cytoplasmic catalase activities are reduced (Figure 4a, Supplementary Figure 4A); CTA1 overexpression has a rescue effect (Figures $1 \mathrm{~d}$ and $2 \mathrm{a}$ ). Moreover, activation of several signaling pathways during nitrogen deprivation is predicted to have deleterious effects on sphingolipid build-up in $\operatorname{csg} 2 \Delta$ cells. To reduce build-up of toxic IPC and/or other sphingolipid precursors in csg2 $\Delta$ cells, sphingolipid synthesis is repressed. ${ }^{11}$ During nitrogen deprivation, TORC1 repression leads to increased sphingolipid synthesis; ${ }^{7,38}$ these conditions are likely to exacerbate IPC 
accumulation in $\operatorname{csg} 2 \Delta$ cells. In addition, amino-acid deprivation is known to activate the Gcn4 transcription factor, which induces Npr1 kinase, also predicted to increase sphingolipid synthesis. ${ }^{39}$ Finally, activated Gcn4 also targets PKA ${ }^{39}$ whose increased activity should repress Snf1/AMPK activity.

Ras/PKA negatively controls Snf1/AMPK in response to nutritional condition. ${ }^{40,41}$ For instance, in plentiful glucose, it is well established that Ras is activated whereas Snf1 is repressed; Snf1 has a critical role in remodeling energy metabolism to increase oxidative phosphorylation upon glucose depletion. ${ }^{42}$ As diagrammed in Figure $5 \mathrm{~d}$, in csg2 $\Delta$ cells, chronic Ras activation and Snf1 inactivation during growth in glucose become unsustainable when cells are deprived of nitrogen. Indeed, constitutively activated Ras2 $2^{\text {Val19 }}$ can bypass absence of glucose to induce death of $\operatorname{csg} 2 \Delta$ cells during nitrogen deprivation (Figure 4d). Similarly, in snf1 $\Delta$ cells, nitrogen deprivation triggers death accompanied by ROS (Figure 5). These results show that Snf1 activity is required to adjust mitochondrial activity depending on nutritional conditions, and Snf1 activation is essential for mitochondrial biogenesis to increase mitochondrial mass. ${ }^{30}$ By contrast with $\operatorname{csg} 2 \Delta$ cells in which Snf1 activity is impaired in conjunction with IPC accumulation, inhibiting sphingolipid synthesis (with myriocin) has been reported to induce Snf1 activity, resulting in upregulation of genes involved in oxidative phosphorylation. $^{12}$

ROS proliferation is a cellular phenotype shared by $\operatorname{csg} 2 \Delta$ cells and human sphingolipidoses, diseases in which sphingolipids build-up abnormally. ${ }^{15}$ Significantly, our work highlights mitochondria and associated metabolic pathways as targets of lipid toxicity. Dysfunctional AMPK signaling has been linked to human metabolic disease (including those induced by lipid overload) and cancer. ${ }^{43}$ Moreover, involvement of Ras and AMPK pathways in regulating sphingolipid metabolism has been suggested in mammalian systems. ${ }^{44,45}$ Our results have implications for human disorders of lipid metabolism as well as obesity-related pathologies.

\begin{abstract}
Materials and Methods
Media, strains and plasmids. Standard medium was as described. ${ }^{46}$ Nitrogen sources in SC medium are all amino acids and $5 \mathrm{~g} / \mathrm{l}$ ammonium sulfate. Strains were in the BY4742/4741 background except as noted. Deletion strains were confirmed by PCR and/or phenotypic analysis. Gene knockouts, marked by resistance to clonNAT, was by transformation with PCR products, as described; ${ }^{47}$ primers available upon request. Some double mutants were constructed by cross and tetrad dissection. RhoO strains were induced by treating with ethidium bromide, as described. ${ }^{48}$ pMET3-RAS2 ${ }^{\text {Val19 }}$, URA3-marked, was from Paul Herman, as described. ${ }^{49}$ pIT517, a URA3-marked centromeric plasmid bearing HA-Snf1-G53R was from Sergei Kuchin, University of Wisconsin-Milwaukee, Milwaukee, WI, USA. ${ }^{50}$ PMET17-CTA1, a URA3-marked centromeric plasmid was from Paula Ludovico (University of Minho, Braga, Portugal). pRBD-GFP, a URA3-marked centromeric plasmid was from Campbell Gourlay, University of Kent, Canterbury, UK. ${ }^{26}$
\end{abstract}

Cell viability assay, western blot, enzyme assay, cell staining with fluorescent dyes. For nitrogen deprivation, cells growing exponentially in SC medium with $2 \%$ glucose were washed with water, and then resuspended in yeast nitrogen base with $2 \%$ glucose. To assay cell viability after 4 -h nitrogen deprivation, cells were diluted to $0.1 \mathrm{OD}_{600} / \mathrm{ml}$ and then plated on YPD plates, and colonies were counted after 2 days. Supplementary Table 1 is an Excel file with absolute colony numbers for cell viability assays. For western blots, cell lysate was prepared by vortexing cells with glass beads with a protease inhibitor cocktail including $1 \mathrm{mM}$ PMSF, as described previously. ${ }^{51}$ Samples were normalized to protein content determined by Bradford assay. Antibody against Cox2, and porin were from Abcam (UK). Anti-PGK1 was from Molecular Probes (Eugene, OR, USA).

Catalase activity was assayed by adding hydrogen peroxide to cell lysate and measuring the rate of decrease of absorbance at $240 \mathrm{~nm}$, as described previously. ${ }^{52}$

For detecting ROS, mid-log cells were washed with phosphate-buffered saline (PBS) and incubated with $5 \mu \mathrm{g} / \mathrm{ml}$ DHE for $15 \mathrm{~min}$; cells were washed once and resuspended in PBS before visualizing with an Olympus (Japan) fluorescent microscope, and images were collected with a Hamamatsu (Japan) CCD camera. For measuring relative MMP in the non-quench mode, live cells were stained with TMRM $(5 \mathrm{nM})$ for $30 \mathrm{~min}$, and then visualized by fluorescence microscopy. DHE and TMRM fluorescence was quantitated by scoring 50 cells per experiment using Image $\mathrm{J}(\mathrm{NIH}$, Bethesda, MD, USA) software.

Lipid mass spectrometry. Cells were grown in YPD to late exponential phase (OD600 between 1 and 2). IPC were extracted from 10 OD units of cells using $95 \%$ ethanol, water, diethyl ether, pyridine and $4.2 \mathrm{~N}$ ammonium hydroxide in a ratio of $15: 15: 5: 1: 0,18$ by volume as described in Guan et al. ${ }^{53}$ Inositol containing lipids were analyzed in the negative ion mode on a Bruker Esquire HCT Ion Trap mass spectrometer (Billerica, MA, USA) using electrospray ionization at a flow rate of $180 \mu \mathrm{l} / \mathrm{h}$ and a spray voltage of $4 \mathrm{kV}$. The relative levels of inositol containing lipids were the same in all strains analyzed.

Mitochondrial isolation, $\mathrm{O}_{2}$ consumption, mitochondrial mass measurement. Mitochondria were isolated as described ${ }^{54}$ except the homogenization step was omitted; instead, spheroplasts were vortexed for $30 \mathrm{~s}$ in water, and then diluted with 1 volume of homogenization buffer. For oxygen measurements, mitochondria were resuspended in an isolation buffer consisting of $200 \mathrm{mM}$ mannitol, $50 \mathrm{mM}$ sucrose, $5 \mathrm{mM} \mathrm{K} \mathrm{HPO}_{4}, 5 \mathrm{mM}$ MOPS, $1 \mathrm{mM}$ EGTA, $0.1 \%$ w/w BSA, pH 7.15 .

Mitochondrial oxygen consumption was measured by adding isolated mitochondria to a respiration buffer consisting $\left(107.5 \mathrm{mM} \mathrm{KCl}, 5 \mathrm{mM} \mathrm{KH}_{2} \mathrm{PO}_{4}, 50 \mathrm{mM}\right.$ MOPS, $1 \mathrm{mM}$ EGTA, $0.1 \%$ w/w BSA essentially fatty acid free, $\mathrm{pH} 7.2$ using $\mathrm{KOH}$ ) in a high resolution Orobos Oxygraph $2 \mathrm{~K}$ at $25^{\circ} \mathrm{C}$ and normalized based on total protein $(100 \mu \mathrm{g}) . \mathrm{O}_{2}$ flux is determined by measuring the fall in $\mathrm{O}_{2}$ concentration in the sealed oxygraph. For whole-cell oxygen consumption, exponentially growing cells were pelleted and resuspended in the specified medium at $20 \mathrm{OD}_{600} / \mathrm{ml}$. Cells were then added into the oxygraph chamber containing the same medium at a concentration of $2 \mathrm{OD}_{600} / \mathrm{ml}$ and $\mathrm{O}_{2}$ flux was followed. When indicated, TET and CCCP were added to a concentration of $10 \mathrm{mM}$

Mitochondrial mass was measured by PCR of POR1 and COX2, and normalized to ACT1 from genomic DNA using primers for a small region of each gene (sequences available upon request).

\section{Conflict of Interest}

The authors declare no conflict of interest.

Acknowledgements. We thank Campbell Gourlay, Paul Herman, Paula Ludovico and Sergei Kuchin for providing plasmids. This study was supported by the University of Michigan Protein Folding Disease Initiative, the Swiss National Science Foundation (31003A_153416) and the NIH (HL072011).

1. Breslow DK. Sphingolipid homeostasis in the endoplasmic reticulum and beyond. Cold Spring Harbor Perspect Biol 2013; 5: a013326.

2. Hannun YA, Obeid LM. Principles of bioactive lipid signalling: lessons from sphingolipids. Nat Rev Mol Cell Biol 2008; 9: 139-150.

3. Aguilera-Romero A, Gehin C, Riezman H. Sphingolipid homeostasis in the web of metabolic routes. Biochim Biophys Acta 2013; 1841: 647-656.

4. Spincemaille P, Cammue BPA, Thevissen K. Sphingolipids and mitochondrial function, lessons learned from yeast. Microbial Cell 2014; 1: 1-15.

5. Penno A, Reilly MM, Houlden H, Laura M, Rentsch K, Niederkofler V et al. Hereditary sensory neuropathy type 1 is caused by the accumulation of two neurotoxic sphingolipids. J Biol Chem 2010; 285: 11178-11187.

6. Loewith R, Hall MN. Target of rapamycin (TOR) in nutrient signaling and growth control. Genetics 2011; 189: 1177-1201.

7. Liu M, Huang CJ, Polu SR, Schneiter R, Chang A. Regulation of sphingolipid synthesis via Orm1 and Orm2 in yeast. J Cell Sci 2012; 125: 2428-2435. 
8. Sun $\mathrm{Y}$, Miao $\mathrm{Y}$, Yamane $\mathrm{Y}$, Zhang $\mathrm{C}$, Shokat $\mathrm{KM}$, Takematsu $\mathrm{H}$ et al. Orm protein phosphoregulation mediates transient sphingolipid biosynthesis response to heat stress via the Pkh-Ypk and Cdc55-PP2A pathways. Mol Biol Cell 2012; 23: 2388-2398.

9. Muir A, Ramachandran S, Roelants FM, Timmons G, Thorner J. TORC2-dependent protein kinase Ypk1 phosphorylates ceramide synthase to stimulate synthesis of complex sphingolipids. eLlfe 2014; 3: e03779.

10. Aronova S, Wedaman K, Aronov PA, Fontes K, Ramos K, Hammock BD et al. Regulation of ceramide biosynthesis by TOR complex 2. Cell Metabol 2008; 7: 148-158.

11. Gururaj $C$, Federman $R$, Chang A. Orm proteins integrate multiple signals to maintain sphingolipid homeostasis. J Biol Chem 2013; 288: 20453-20463.

12. Liu J, Huang X, Withers BR, Blalock E, Liu K, Dickson RC. Reducing sphingolipid synthesis orchestrates global changes to extend yeast lifespan. Aging Cell 2013; 12: 833-841.

13. Yucel EB, Ulgen KO. Assessment of crosstalks between the Snf1 kinase complex and sphingolipid metabolism in S. cerevisiae via systems biology approaches. Mol Biosyst 2013; 9: 2914-2931.

14. Uemura S, Kihara A, Iwaki S, Inokuchi J, Igarashi Y. Regulation of the transport and protein levels of the inositol phosphorylceramide mannosyltransferases Csg1 and Csh1 by the $\mathrm{Ca}^{2+}$-binding protein Csg2. J Biol Chem 2007; 282: 8613-8621.

15. Vitner EB, Platt FM, Futerman AH. Common and uncommon pathogenic cascades in lysosomal storage diseases. J Biol Chem 2010; 285: 20423-20427.

16. Broach JR. Nutritional control of growth and development in yeast. Genetics 2012; 192: 73-105.

17. Yamagata M, Obara K, Kihara A. Unperverted synthesis of complex sphingolipids is essential for cell survival under nitrogen starvation. Genes Cells 2013; 18: 650-659.

18. Sato K, Noda Y, Yoda K. Kei1: a novel subunit of inositolphosphorylceramide synthase, essential for its enzyme activity and Golgi localization. Mol Biol Cell 2009; 20: 4444-4457.

19. Campian JL, Qian M, Gao X, Eaton JW. Oxygen tolerance and coupling of mitochondrial electron transport. J Biol Chem 2004; 279: 46580-46587.

20. Mesquita A, Weinberger M, Silva A, Sampaio-Marques B, Almeida B, Leao C et al. Caloric restriction or catalase inactivation extends yeast chronological lifespan by inducing $\mathrm{H}_{2} \mathrm{O}_{2}$ and superoxide dismutase activity. Proc Natl Acad Sci USA 2010; 107: 15123-15128.

21. Perry SW, Norman JP, Barbieri J, Brown EB, Gelbard HA. Mitochondrial membrane potential probes and the proton gradient: a practical usage guide. Biotechniques 2011; 50: 98-115.

22. Mendes-Ferreira A, del Olmo M, Garcia-Martinez J, Jimenez-Marti E, Mendes-Faia A, Perez-Ortin JE et al. Transcriptional response of Saccharomyces cerevisiae to different nitrogen concentrations during alcoholic fermentation. Appl Environ Microbiol 2007; 73: 3049-3060.

23. Johnson MA, Vidoni S, Durigon R, Pearce SF, Rorbach J, He J et al. Amino acid starvation has opposite effects on mitochondrial and cytosolic protein synthesis. PLOS ONE 2014; 9: e93957.

24. Bourens M, Fontanesi F, Soto IC, Liu J, Barrientos A. Redox and reactive oxygen species regulation of mitochondrial cytochrome c oxidase biogenesis. Antioxid Redox Signal 2013; 19: 1940-1952.

25. Jazwinski SM. The retrograde response: when mitochondrial quality control is not enough. Biochim Biophys Acta 2013; 1833: 400-409.

26. Leadsham JE, Miller K, Ayscough KR, Colombo S, Martegani E, Sudbery P et al. Whi2p links nutritional sensing to actin-dependent Ras-cAMP-PKA regulation and apoptosis in yeast. J Cell Sci 2009; 122: 706-715.

27. Belloti F, Tisi R, Paiardi C, Rigamonti M, Groppi S, Martegani E. Localization of Ras signaling complex in budding yeast. Biochim Biophys Acta 2012; 1823: 1208-1216.

28. Bissinger PH, Wieser R, Hamilton B, Ruis H. Control of Saccharomyces cerevisiae catalase T gene (CTT1) expression by nutrient supply via the RAS-cyclic AMP pathway. Mol Cell Biol 1989; 9: 1309-1315.

29. Engelberg D, Zandi E, Parker CS, Karin M. The yeast and mammalian Ras pathways control transcription of heat shock genes independently of heat shock transcription factor. Mol Cell Biol 1994; 14: 4929-4937.
30. Hardie DG, Ross FA, Hawley SA. AMPK: a nutrient and energy sensor that maintains energy homeostasis. Nat Rev Mol Cell Biol 2012; 13: 251-262.

31. Hedbacker K, Carlson M. Snf1/AMPK pathways in yeast. Front Biosci 2009; 13: 2408-2420.

32. Dombek KM, Young ET. Cyclic AMP-dependent protein kinase inhibits ADH2 expression in part by decreasing expression of the transcription factor gene ADR1. Mol Cell Biol 1997; 17: $1450-1458$.

33. Estruch F, Treitel MA, Yang X, Carlson M. N-terminal mutations modulate yeast SNF1 protein kinase. Genetics 1992; 132: 639-650.

34. Fontanesi $F$, Soto IC, Barrientos A. Cytochrome $c$ oxidase biogenesis: new levels of regulation. IUBMB Life 2008; 60: 557-568.

35. Kim A, Davis R, Higuchi M. Intracellular oxygen determined by respiration regulates localization of Ras and prenylated proteins. Cell Death Differ 2015; 6: e1825.

36. Barros MH, Bandy B, Tahara EB, Kowaltowski AJ. Higher respiratory activity decreases mitochondrial reactive oxygen release and increases life span in Saccharomyces cerevisiae. J Biol Chem 2004; 279: 49883-49888.

37. Shaw RJ. LKB1 and AMPK control of mTOR signalling and growth. Acta Physiol 2009; 196 $65-80$

38. Shimobayashi M, Oppliger W, Moes S, Jeno P, Hall MN. TORC1-regulated protein kinase Npr1 phosphorylates Orm to stimulate complex sphingolipid synthesis. Mol Biol Cell 2013; 24: 870-881.

39. Natarajan K, Meyer MR, Jackson BM, Slade D, Roberts C, Hinnebusch AG et al. Transcriptional profiling shows that Gcn4p is a master regulator of gene expression during amino acid starvation in yeast. Mol Cell Biol 2001; 21: 4347-4368.

40. Barrett L, Orlova M, Maziarz M, Kuchin S. Protein kinase A contributes to the negative control of Snf1 protein kinase in Saccharomyces cerevisiae. Eukaryotic Cell 2012; 11: 119-128.

41. Hubbard EJA, Yang X, Carlson M. Relationship of the cAMP-dependent protein kinase pathway to the SNF1 protein kinase and invertase expression in Saccharomyces cerevisiae. Genetics 1992; 130: 71-80.

42. Wilson WA, Hawley SA, Hardie DG. Glucose repression/derepression in budding yeast SNF1 protein kinase is activated by phosphorylation under derepressing conditions, and this correlates with a high AMP:ATP ratio. Curr Biol 1996; 6: 1426-1434.

43. Viollet B, Horman S, Leclerc J, Lantier L, Foretz M, Billaud M et al. AMPK inhibition in health and disease. Crit Rev Biochem Mol Biol 2010; 45: 276-295.

44. Gault CR, Ebien ST, Neumann CA, Hannun YA, Obeid LM. Oncogenic K-Ras regulates bioactive sphingolipids in a sphingosine kinase 1-dependent manner. J Biol Chem 2012; 287: 31794-31803.

45. Choi S, Snider AJ. Sphingolipids in high fat diet and obesity-related diseases. Mediators Inflamm 2015; 2015: 520618

46. Sherman F, Hicks JB, Fink GR. Methods in Yeast Genetics: A Laboratory Manual. Cold Spring Harbor Laboratory Press: Cold Spring Harbor, NY, USA, 1986.

47. Goldstein AL, McCusker JH. Three new dominant drug resistance cassettes for gene disruption in Saccharomyces cerevisiae. Yeast 1999; 15: 1541-1553.

48. Fox TD, Folley LS, Mulero JJ, McMullin TW, Thorsness PE, Hedin LO et al. Analysis and manipulation of yeast mitochondrial genes. Methods Enzymol 1991; 194: 149-165.

49. Ramachandran V, Herman PK. Antagonistic interactions between the cAMP-dependent protein kinase and Tor signaling pathways modulate cell growth in Saccharomyces cerevisiae. Genetics 2010; 187: 441-454.

50. Orlova M, Kanter E, Krakovich D, Kuchin S. Nitrogen availability and TOR regulate the Snf protein kinase in Saccharomyces cerevisiae. Eukaryotic Cell 2006; 5: 1831-1837.

51. Chang A, Slayman CW. Maturation of the yeast plasma membrane $\left[\mathrm{H}^{+}\right] A T P a s e$ involves phosphorylation during intracellular transport. J Cell Biol 1991; 115: 289-295.

52. Jakubowski W, Bilinski T, Bartosz G. Oxidative stress during aging of stationary cultures of the yeast Saccharomyces cerevisiae. Free Radic Biol Med 2000; 28: 659-664.

53. Guan XL, Riezman I, Wenk MR, Riezman $\mathrm{H}$. Yeast lipid analysis and quantification by mass spectrometry. Methods Enzymol 2010; 470: 369-391.

54. Meisinger C, Pfanner N, Truscott KN. Isolation of yeast mitochondria. Methods Mol Biol 2006 313. $33-39$

\section{Supplementary Information accompanies this paper on Cell Death and Differentiation website (http://www.nature.com/cdd)}

